\title{
Kryzys migracyjny w Unii Europejskiej z perspektywy Bałkanów Zachodnich
}

\section{Wprowadzenie}

Najpoważniejszy egzamin europejskiej jedności jakim okazał się kryzys migracyjny ujawnił słabości Unii Europejskiej, która w czasach stabilizacji odzwierciedla wszystkie idee utożsamiane ze wspólnotowością, jednakże w czasach kryzysów na sile przybierają antagonizmy i partykularyzm. Zarazem, o czym świadczy systematyczny rozwój i pogłębianie współpracy w ramach UE, to kryzysy stanowiły jej siłę napędową. W literaturze formułowany jest pogląd, iż zjawiska kryzysowe zarówno te o wewnątrzunijnej genezie, jak również te będące następstwem procesów globalnych oraz zjawisk zachodzących w bliższym i dalszym otoczeniu Unii stały się nieodzowną, immanentną cechą procesów integracyjnych z jednej strony, osłabiając jej funkcjonowanie, z drugiej zaś, stymulując do przekształceń (Wojtaszczyk, Nadolska, Czub, 2014, s. 10; Fiszer, 2015, s. 84). W tym miejscu można przytoczyć również opinię Jacka Saryusza-Wolskiego, który zauważa, iż od początku istnienia wspólnoty europejskiej kryzys był pewnym modus vivendi, a czasami odgrywał rolę hamulca albo - wręcz odwrotnie - stymulatora jej przeobrażeń (Saryusz-Wolski, 2013, s. 3). Kryzys migracyjny z całą pewnością stanowi punkt zwrotny w funkcjonowaniu UE, nie tylko ujawnia zróżnicowany charakter czynników ją osłabiających (zarówno wewnątrzunijnych, jak i tych mających swoje źródło w sytuacji zewnętrznej), ale przede wszystkim obliguje do działań reformatorskich i modernizacyjnych.

Reperkusje kryzysu migracyjnego z perspektywy UE mogą mieć zarówno negatywny, jak również pozytywny wymiar. Koncentrując uwagę na doraźnych problemach napływu uchodźców i imigrantów ekonomicznych, w tym m.in. trudnościach $\mathrm{w}$ ich identyfikacji, kosztach związanych z zarządzaniem przepływami migracyjnymi, wzmacnianiem i kontrolą granic, wsparciem socjalnym pomija się skutki z perspektywy długoterminowej (Managing the EU, 2016). Ekonomiczne, społeczne czy w końcu polityczno-prawne implikacje kryzysu mogą okazać się korzystne dla UE. Kryzys wymaga zdecydowanych działań, podejmowania nierzadko niepopularnych i trudnych decyzji, które w konsekwencji nadają nowy impuls organizacji, której to dotyczy. Taką funkcję pełni dziś kryzys migracyjny, który nie tylko aktywizuje instytucje europejskie, ale również uświadamia unijnym decydentom konsekwencje zaniechania działań w obszarach, które dziś stanowią o skuteczności reagowania UE na masowy, niekontrolowany napływ ludności na jej terytorium. Mając na uwadze, iż termin kryzys jest niekiedy określany i definiowany w powiązaniu z pojęciem normalności oznacza on zatem pewną formę wyraźnego odstępstwa od tego co jest akceptowalne (Lindley, 2014, s. 2). Napływ ludności na terytorium UE (z państw trzecich) jest zjawiskiem 
naturalnym o ile jest ono kontrolowane, regulowane, i co ważne, akceptowane. Współcześnie, masowość napływu migrantów i niekontrolowany jej charakter, stanowiąc wspomniane odstępstwo od stanu możliwego do zaakceptowania, determinuje negatywną percepcję sytuacji, w której znalazła się UE.

W tym miejscu należy zauważyć, iż napływ ludności na terytorium UE zintensyfikowany jesienią 2015 roku, a mający swe źródło w wydarzeniach tzw. Arabskiej Wiosny należy rozpatrywać zarówno jako kryzys uchodźczy, jak i szerzej jako kryzys migracyjny (Potyrała, 2015, s. 34). Przy czym nie ma zgodności co do tego czy mamy do czynienia z kryzysem migracyjnym, uchodźczym, azylowym czy też ze szczególną postacią kryzysu politycznego Unii. Jednakowoż, jak zauważa Maciej Cesarz, w sensie terminologicznym określenia „kryzys migracyjny” lub „kryzys uchodźczy” oddają najlepiej naturę obecnego kryzysu, podkreślając jego skalę i wymiar demograficzny związany z napływem znacznej liczby ludzi na terytorium Europy w krótkim okresie czasu. Dodatkowo w ocenie przywołanego Autora pojęcie kryzys migracyjny uwypukla dodatkowo następstwa socjoekonomiczne związane z przepływem osób, dla których Europa nie jest terytorium tranzytu, lecz miejscem docelowym migracji, z którym wiążą wolę pobytu stałego. W jego ocenie z perspektywy UE należałoby raczej mówić o kryzysie uchodźczym i migracyjnym jednocześnie, szczególnie uwzględniając mieszany charakter przepływów migracyjnych, jaki odnotowuje się obecnie na terytoriach państw członkowskich (Cesarz, 2016, s. 98). Charakter zjawiska, z jakim zmaga się współcześnie Europa, pozwala przyjaćc, iż mamy do czynienia z dwuwymiarowym kryzysem. W opinii Marty Pachockiej z jednej strony jest to kryzys migracyjny w ujęciu demograficznym, który charakteryzuje się napływem dużej liczby ludności w krótkim czasie, z drugiej zaś to największy powojenny kryzys uchodźczy, który przejawia się rosnącą liczbą osób opuszczających kraj pochodzenia lub ostatnie miejsce stałego zamieszkania w poszukiwaniu azylu (Pachocka, 2016, s. 1).

Punktem wyjścia do dalszych analiz jest przyjęcie założenia, iż kryzys migracyjny to poważne dysfunkcjonalne zjawisko kulturowe, społeczne, ekonomiczne i polityczne niosące rozbudowany katalog ryzyk i zagrożeń dla całej Europy, w tym UE (Czachór, Jaskólski, 2015, s. 17-18). Należy mieć na uwadze fakt, iż zjawisko polegające ma masowym i niekontrolowanym przemieszczaniu się grup ludności z jednego terytorium na inne, której towarzyszy czasowa lub stała zmiana pobytu nie jest zjawiskiem nowym w europejskiej rzeczywistości. Cyklicznie z uwagi na rozwój sytuacji w otoczeniu UE stawała się celem podróży zarówno dla osób poszukujących wsparcia i ochrony przez wojnami i konfliktami, jak i tych poszukujących możliwości poprawy własnej sytuacji materialnej. Współcześnie, z uwagi na skalę i dynamikę zjawiska, jak nigdy dotąd zarządzanie migracjami stało się wyzwaniem dla struktur europejskich. Wzrost migracji stał się największym i najbardziej wymagającym wyzwaniem dla UE, a zarazem niezwykle wrażliwą kwestią polityczną, wywołującą ostrą debatę polityczną i publiczną, i co ważne, pogłębiającą istniejące problemy w polityce imigracyjnej UE (Metcalfe-Hough, 2015). Równocześnie wykazał brak gotowości instytucji UE do radzenia sobie w sytuacjach kryzysowych i uwypuklił niedoskonałości w mechanizmach współpracy europejskiej. Przede wszystkim wykazał brak solidarności i zróżnicowanie interesów pośród państw członkowskich (Duszczyk, 2015; Bonikowska, Szczygielski, Zabielski, 2016). Kryzys migracyjny 
uwidocznił fakt, iż wiele państw priorytetowo traktuje interesy narodowe ponad solidarnością europejską, rezygnując z ponoszenia współodpowiedzialności za jego rozwiązanie (Greenhill, 2016, s. 317).

Jak zauważa Paweł Borkowski, dotychczasowe rozwiązania przyjęte w UE w zakresie kontroli i regulacji przepływu osób sprawdzały się jednak połowiczne i zostały przetestowane w 2015 roku. Okazało się w ocenie przywołanego Autora, że UE nie jest zdolna poradzić sobie z problemem pod każdym względem: politycznym - państwa nie były w stanie uzgodnić wspólnego stanowiska; biurokratyczno-organizacyjnym - zbyt mało zasobów, aby wobec przybyszy stosować przewidziane prawem rozwiązania; solidarności - kraje ,graniczne” pozostawiono w zasadzie samym sobie (Borkowski, 2016, s. 43). Dodatkowo, jak zauważa Ryszard Zięba, obawy przed konsekwencjami społeczno-ekonomicznymi i kulturowymi przyjęcia imigrantów, a także przed nasilającym się terroryzmem, jakie formułuje część państw członkowskich, stwarzają poczucie wysokiego zagrożenia dla bezpieczeństwa wewnętrznego państw członkowskich Unii (Zięba, 2016, s. 24). Tak formułowane obawy jedynie wzmacniają stanowiska tych państw członkowskich, które konsekwentnie sprzeciwiają się proponowanym przez unijne instytucje rozwiązaniom, które pozwoliłyby na opanowanie kryzysu i ograniczenie jego negatywnych następstw.

Przy czym konsekwencje napływu ludności na terytorium UE ponoszą nie tylko państwa członkowskie, które mają charakter państw docelowych, ale również państwa znajdujące się na szlaku przerzutu migrantów tzw. państwa tranzytowe. Abstrahując od eksplantacji czynników determinujących kryzys migracyjny w UE warto przeanalizować implikacje kryzysu migracyjnego z perspektywy terytorium ściśle powiązanego z UE, a mianowicie państw Bałkanów Zachodnich. Pojęciem tym posługuje się od 1999 roku UE, która wobec regionu od lat prowadzi działania ukierunkowane na stabilizację i umacnianie bezpieczeństwa militarnego, ekonomicznego, społecznego przez sukcesywne i coraz ściślejsze powiązanie go ze wspólnotą europejską (Bokajło, 2008, s. 349). W tym miejscu zaznaczyć należy, iż przedmiotem analizy poza Chorwacją jest Albania, Bośnia i Hercegowina, Była Jugosłowiańska Republika Macedonii (FYROM), Czarnogóra, Serbia i Kosowo (w rozumieniu rezolucji Rady Bezpieczeństwa ONZ 1244 oraz z uwzględnieniem opinii Międzynarodowego Trybunału Sprawiedliwości w sprawie deklaracji niepodległej Kosowa). Są to państwa geograficznie przynależne do regionu, aspirujące do członkostwa w UE i objęte jej polityką rozszerzenia. W odróżnieniu od Chorwacji, która w 2013 roku uzyskała członkostwo w UE pozostałe państwa aspirują do akcesji w tej organizacji.

Artykuł ma na celu zweryfikowanie hipotezy, że kryzys migracyjny ze względu na swój złożony charakter powoduje zróżnicowane konsekwencje w wielu dziedzinach nie tylko dla państw członkowskich, ale również państw zlokalizowanych w bliskim sąsiedztwie, w tym państw Bałkanów Zachodnich. Artykuł koncentruje się na implikacjach kryzysu migracyjnego dla państw zachodniobałkańskich, które można rozpatrywać na kilku poziomach. Po pierwsze, należy mieć na uwadze konsekwencje, jakie wywołuje kryzys migracyjny na poziomie poszczególnych państw, chociażby w kontekście bezpieczeństwa tychże. Po drugie, należy zwrócić uwagę na możliwe implikacje kryzysu dla charakteru i dynamiki relacji dwustronnych oraz współpracy regionalnej. Trzeci zaś, to relacje UE - państwa Bałkanów Zachodnich. 


\section{Charakter i specyfika zagrożeń dla bezpieczeństwa państw Bałkanów Zachodnich w kontekście kryzysu migracyjnego}

Kryzys migracyjny z uwagi na swą naturę implikuje szereg negatywnych zjawisk, które dotyczą nie tylko tych państw Unii Europejskiej, które z uwagi na swój potencjał stanowią punkt docelowy dla uchodźców i imigrantów ekonomicznych, ale również dla tych państw, przez terytoria których wiedzie szlak migracyjny. Konsekwencje kryzysu zachodzą na wielu płaszczyznach i dotyczą wielu segmentów aktywności państw, w tym gospodarki, polityki wewnętrznej i zewnętrznej, bezpieczeństwa, ochrony praw człowieka, zarządzania kryzysowego, pomocy humanitarnej. Mając na uwadze charakter zjawiska, jego skalę i dynamikę z następstwami kryzysu zmagają się zarówno te państwa, do których trafia największa liczba migrantów (głównie państwa Europy Zachodniej i Północnej), jak również i te, które stanowią funkcję tranzytu, w tym przypadku stanowiące przedmiot analizy państwa Bałkanów Zachodnich. Przy czym te ostatnie, z uwagi na swój potencjał, nie tylko, że nie dysponują zdolnościami do skutecznego przeciwdziałania i reagowania na kryzys migracyjny, ale również ich mieszkańcy, korzystając z zaistniałej sytuacji, usiłują przedostać się na terytorium państw członkowskich UE. Dodatkowo państwa zachodniobałkańskie obarczone spuścizną kolejnych odsłon konfliktów na obszarze byłej Jugosławii (Bośnia i Hercegowina w latach 1992-1995, Kosowo w latach 1996-1999, Macedonia w 2001 roku) należą do szczególnie wrażliwych na wszelkie sytuacje kryzysowe (zob. Podgórzańska, 2014).

Dopełnieniem powyższego jest stwierdzenie, iż skala i charakter zagrożeń dla bezpieczeństwa zależna jest od tego czy mamy do czynienia z państwem docelowym, czy tranzytowym. Państwa Bałkanów Zachodnich z uwagi na status państwa tranzytowego w mniejszym stopniu ponoszą konsekwencje kryzysu migracyjnego, niż Grecja czy Włochy, do których w pierwszej kolejności trafiają imigranci, czy też państwa docelowe jak chociażby Niemcy. Zarazem nie oznacza to braku reperkusji napływu imigrantów na ich terytorium chociażby w kontekście wspomnianego bezpieczeństwa wewnętrznego. Niezależnie, iż państwa zachodniobałkańskie pełnią jedynie funkcję tranzytu dla imigrantów spoczywają na nich określone obowiązki związane z udzieleniem wsparcia i ochrony migrującym, którym z uwagi na swoje możliwości nie mogą sprostać. Wypełnienie zobowiązań wynikających z potrzeby humanitarnego traktowania migrantów wymaga finansowych i organizacyjnych zdolności. Państwa Bałkanów Zachodnich, mając ograniczone możliwości, oczekiwały aktywności ze strony instytucji unijnych podkreślając, iż sytuacja państw tranzytowych nieunijnych jest bardziej skomplikowana niż państw unijnych tranzytowych i docelowych (Sprawozdanie, 2015). Same, za pomocą środków jednostronnych, na co wskazywał m.in. minister spraw zagranicznych Serbii Ivica Dacic, bez pomocy UE nie były zdolne rozwiązać problemu dużej liczby uchodźców z Bliskiego Wschodu (Дачић: србија, 2015). Problem z migrantami i uchodźcami wymaga wspólnego zaangażowania wszystkich podmiotów, z uwzględnieniem zarówno zobowiązań międzynarodowych, jak i poszanowaniem interesów wszystkich zaangażowanych państw i organizacji (Пронаћи, 2017). Opieszałość, jaka towarzyszyła Unii w początkowym stadium kryzysu, powodowała formułowanie zarzutów o niedostateczną reakcję ze strony instytucji europej- 
skich. Państwa zachodniobałkańskie, nie radząc sobie z presją migracyjną, oczekiwały wsparcia w zarządzaniu migracją. Równolegle sięgały po pozostające w ich dyspozycji środki, które w ich ocenie miały przynajmniej czasowo zahamować napływ imigrantów (Kryzys migracyjny, 2016). Co więcej, należy zauważyć, iż ani docelowe dla migrantów państwa Europy Zachodniej i Północnej, ani państwa tranzytowe zaskoczone skalą i dynamiką zjawiska nie były zdolne do szybkiej i efektywnej reakcji. Dopiero z czasem, i co ważne, wskutek presji tragicznych wydarzeń, jakie towarzyszyły napływowi migrantów, zintensyfikowano działania polityczne w UE.

Warto również nadmienić, iż państwa Bałkanów Zachodnich to nie tylko państwa tranzytowe dla migrantów, ale również państwa ich pochodzenia. Podkreślić należy, iż mieszkańcy tego regionu wykorzystują presję, jaka towarzyszy napływowi imigrantów, do tego by migrować do zasobnych państw Europy Zachodniej i Północnej. Pomimo, iż region ten jest objęty polityką rozszerzenia UE perspektywa akcesji jest jednak odległa. Zarówno tempo procesu integracji europejskiej, jak również poziom rozwoju gospodarczego regionu to dziś główne determinanty migracji (Niekontrolowane, 2015, s. 30-36). W konsekwencji, pośród osób migrujących nielegalnie na terytorium UE znajdują się także mieszkańcy z regionu Zachodnich Bałkan, przede wszystkim mieszkańcy Kosowa, a także Albanii (Kosowski, 2015). Przy czym nadmienić należy, iż mają oni znikome szanse na uzyskanie azylu w państwach członkowskich UE. Według danych Eurostatu, za ostatni kwartał 2016 roku spośród 8300 decyzji w pierwszej instancji wydawanych Albańczykom tylko 200 było pozytywnych (3\% uznania). Podczas gdy spośród 4500 wydanych dla obywateli Kosowa i 4100 dla Serbów tylko 300 i 100 były pozytywne (odpowiednio 7\% i 2\%) (Asylum quarterly report, 2017). W ciagu całego 2016 roku wskaźnik pozytywnych decyzji w sprawie przyznania azylu dla obywateli wywodzących się z obszaru Bałkan Zachodnich był mniejszy niż 5\% (dla mieszkańców Kosowa - 4,9\%, Albanii - 3,1\%, Serbii - 1,7\%, FYROM - 0,6\%) (Asylum decisions in the EU, 2017).

Celem uporządkowania dalszego wywodu należy podkreślić tranzytowy charakter państw zachodniobałkańskich. Równocześnie należy mieć na uwadze, iż stopień obciążenia poszczególnych państw regionu napływem imigrantów zależny był od przebiegu szlaków migracyjnych. Szczególne obowiązki spoczywały na tych znajdujących się bezpośrednio na trasie wędrówek migrantów. Pozostałe państwa jak np. Albania, Bośnia i Hercegowina czy Czarnogóra w mniejszym stopniu odczuwały presję migracyjną. Przy czym starały się również przygotować na ewentualne przybycie imigrantów i udzielania im pomocy humanitarnej (Biernat, 2015, s. 4-5). Z raportu Agencji Frontex, poświęconego analizie ryzyka migracyjnego, obejmującego region Bałkanów Zachodnich wynika, iż w ostatnim kwartale 2016 roku liczba nielegalnych przekroczeń granic zgłoszonych przez państwa Bałkanów Zachodnich i państw sąsiednich zdecydowanie spadła w stosunku do analogicznego kwartału w 2015 roku i wynosiła 13638 (1 334731 w IV kwartale 2015 roku). Najwięcej nielegalnych przekroczeń zanotowano na granicy bułgarsko-serbskiej oraz węgiersko-serbskiej. Dominowali obywatele Afganistanu, Pakistanu, Albanii, Iraku, Syrii. Ponadto sześć państw Bałkanów Zachodnich zgłosiło 749 wykrytych nielegalnych pobytów (dominowali obywatele Serbii - 589 oraz Albanii - 240). Liczba ta była o 5\% niższa od analogicznego trzymiesięcznego okresu w 2015 roku. Przy czym należy mieć na uwadze, iż liczba 
wykrytych przypadków była stosunkowo niska w porównaniu z przepływami migracyjnymi w regionie (Western Balkans Quarterly, 2017). Zarazem jednak presja migracyjna na Bałkanach Zachodnich pomimo podjętych działan dotyczących kontroli nad przepływami migracyjnymi pozostaje głównym wyzwaniem UE.

Niezależnie od skali napływu imigrantów do poszczególnych państw tranzytowych rosła obawa przed potencjalnymi zagrożeniami dla bezpieczeństwa i stabilności politycznej i gospodarczej regionu. W odpowiedzi podejmowano działania, które miały na celu z jednej strony udzielenie pomocy imigrantom, z drugiej zaś przeciwdziałanie potencjalnym zagrożeniom dla bezpieczeństwa. Podkreślano bowiem, iż migranci mogą być przyczyną trudności gospodarczych i obciążeniem dla budżetu państw. Wskazywano na możliwą dezorganizację społeczną na obszarach tranzytu migrantów, nielegalne przekraczania granicy państwowej, zakłócanie porządku publicznego, potencjalne starcia ze służbami odpowiedzialnymi za bezpieczeństwo (Мигрантска, 2017). Akcentowano wzrost działalności zorganizowanych grup przestępczych, które zajmując się przemytem czerpią korzyści z nielegalnego dotarcia przez migrantów $\mathrm{z}$ kraju pochodzenia do wybranego kraju docelowego. Ponadto zorganizowane grupy czerpią kolosalne zyski z pobierania od imigrantów wysokich opłat za wyrobienie fałszywych dokumentów i ich przewóz przez granice państwowe (Kotowska, Pływaczewski, 2015, s. 80). W konsekwencji głównymi beneficjentami kryzysu migracyjnego stają się grupy przestępcze, które specjalizują się nie tylko w przemycie ludzi, ale również udostępnianiu informacji dotyczących procedur azylowych i przygotowania fałszywych dokumentów, najczęściej syryjskich (Kryzys imigracyjny, 2016). Pamiętać należy, iż państwa Bałkanów Zachodnich, ze względu na wciąż niestabilną sytuację polityczna, pozostają najbardziej zagrożonym rozwojem przestępczości, w tym zwłaszcza przestępczości zorganizowanej i transgranicznej regionem Europy (Przestępczość, 2007).

Z punktu widzenia państw tranzytowych, jakimi są państwa Bałkanów Zachodnich (jak również państw docelowych), istotnym aspektem kryzysu migracyjnego jest jego wpływ na poziom zagrożenia terroryzmem. Co ważne, problem terroryzmu identyfikowanego jako następstwo migracji powoduje opór przed przyjmowaniem imigrantów w krajach europejskich, a przede wszystkim stygmatyzowanie imigrantów (uchodźców i imigrantów ekonomicznych) jako osoby zagrażające bezpieczeństwu. Informacje, iż wśród imigrantów i uchodźców mogą znajdować się terroryści lub osoby z nimi współpracujące wzmacniają niechęć opinii publicznej (Wojciechowski, 2016, s. 148). Kraje europejskie to nie tylko cele ataków terrorystycznych, lecz również obszar rekrutacji potencjalnych zamachowców, teren pozyskiwania funduszy na działalność terrorystyczną oraz miejsce realizacji działań propagandowych ukierunkowanych na radykalizację postaw i zachowań (Raczyński, 2015, s. 17). Realność zagrożenia incydentami o takim podłożu, jak również - co istotne - przypadki infiltrowania i radykalizowania środowisk muzułmańskich i werbowania nowych bojowników tzw. Państwa islamskiego jedynie wzmacniają antyimigranckie postawy zarówno w państwach członkowskich UE, jak również państwach Bałkanów Zachodnich. Zagrożenie o takim podłożu dostrzegały m.in. władze w Macedonii. W tym miejscu przytoczyć można opinię Nikoli Poposkiego, ministra spraw zagranicznych byłej jugosłowiańskiej Republiki Macedonii, który wskazywał na potencjalne zagrożenie terroryzmem podkreśla- 
jąc, iż wielu bojowników islamskich infiltruje Macedonię (Sprawozdanie, 2015). Przy czym należy zauważyć, iż potencjalny wzrost zagrożenia terroryzmem w regionie wiązał się nie tylko z kryzysem migracyjnym. Zauważyć bowiem należy, iż w krajach bałkańskich niemal od dwóch dekad obserwuje się zjawisko islamskiej radykalizacji społeczeństwa. Sprzyja temu struktura narodowościowa państw powstałych w wyniku rozpadu b. Jugosławii. Nadmienić należy, iż zarówno w BiH, Albanii, Kosowie, jak i w każdym innym państwie bałkańskim ludność muzułmańska stanowi dużą liczebnie mniejszość (Izak, 2013, s. 52). Jednocześnie niebezpiecznym zjawiskiem, które może zakłócić funkcjonowanie tych jakże złożonych struktur narodowościowych jest zarówno potencjalny konflikt pomiędzy muzułmanami i niemuzułmanami, jak również konflikty w łonie samej społeczności muzułmańskiej, co również skutkować może destabilizacją sytuacji politycznej w regionie. Przykładem jest chociażby systematyczny wzrost wpływów wahhabickiej ideologii w BiH. Przy czym działalność wahhabitów jest zagrożeniem nie tylko dla $\mathrm{BiH}$, ale również i innych państw bałkańskich, w których funkcjonują te wspólnoty. Wzrost aktywności islamskich ekstremistów obserwowany jest również w Albanii i Kosowie. Potwierdzają to coraz częstsze przypadki aresztowań pod zarzutem prowadzenia aktywności wspierającej działalność terrorystyczną (np. aresztowanie w 2014 roku dwóch samozwańczych imamów w Albanii pod zarzutem rekrutacji dżihadystów do grup islamistycznych w Syrii) bądź też zarzuty o bezpośrednie organizowanie działań o podłożu terrorystycznym (np. aresztowanie pod koniec 2015 roku w Kosowie sześciu mężczyzn oskarżonych o działalność terrorystyczna). Coraz liczniejsze doniesienia o tego rodzaju incydentach, zdaniem Magdaleny El. Ghamari, wskazują na rosnącą skalę zagrożenia terroryzmem w tym regionie (El Ghamari, 2016). Zarazem, co należy podkreślić, wynikiem ich działalności może być wzrost zagrożenia bezpieczeństwa wewnętrznego, w tym przede wszystkim wzrost zagrożenia działalnością terrorystyczną zarówno w krajach bałkańskich, jak również w Europie Zachodniej i Północnej (Izak, 2013).

Konkludując tę część artykułu należy zauważyć, iż sama obecność czy tranzyt migrantów (zarówno uchodźców, jak i imigrantów ekonomicznych) przez terytorium państw Bałkanów Zachodnich nie są równoznaczne ze wzrostem zagrożeń o charakterze terrorystycznym w Europie. Pomimo, iż pośród migrantów znajdują się bojownicy państwa islamskiego, ich obecność w Europie zdaniem służb europejskich nie wpłynęła zasadniczo na wzrost zagrożenia terrorystycznego. Przytoczyć w tym miejscu można wnioski płynące z raportu Europolu z czerwca 2017 roku, który wyraźnie wskazuje na trwającą od trzech lat tendencję spadkową, jeśli chodzi o liczbę przeprowadzanych ataków terrorystycznych w Europie. Drugim istotnym wnioskiem, który formułuje Europol jest stwierdzenie, iż nie da się powiązać fali uchodźców próbujących osiedlić się w Europie ze wzrostem zagrożenia terrorystycznego. Według danych tej agencji statystycznie zwolennicy tzw. Państwa Islamskiego dopuścili się w 2016 roku niespełna 10\% zamachów (13 ze 142 zamachów). Jednakże jak zauważają jego autorzy, ich akty terroru pochłonęły najwięcej ofiar (European Union, 2017). Ta ostatnia konkluzja płynąca z raportu wskazuje jednak, iż potencjalnie działalność bojowników islamskich z uwagi na liczbę ofiar, jak również skalę zniszczeń materialnych, jakie wiążą się $\mathrm{z}$ atakami terrorystycznymi stanowi szczególne zagrożenie dla bezpieczeństwa państw europejskich tak w wymiarze wewnętrznym, jak i zewnętrznym. Wprawdzie anali- 
za sytuacji jakiej dokonano w raporcie dotyczy terytorium UE, jednakże implikacje zagrożeń terrorystycznych należy rozpatrywać w szerszym kontekście nie tylko dla państw członkowskich UE i ich obywateli, ale również dla otoczenia UE.

Charakter zagrożeń dla bezpieczeństwa państwa i społeczeństwa, w tym zagrożenie terroryzmem i radykalizmem powoduje negatywne reakcje opinii publicznej zarówno w państwach członkowskich UE, jak i nieunijnych państwach tranzytowych. Warto nadmienić, iż migracja i terroryzm są przez obywateli konsekwentnie postrzegane jako największe wyzwania dla bezpieczeństwa UE (Wyzwania, 2016). Co ważne również w debacie politycznej, wykorzystuje się kryzys migracyjny jako element, wokół którego ogniskują się spory polityczne i dotyczy to tak państw unijnych, jak i nieunijnych zmagających się z tym problemem. Kryzys migracyjny może stać się zarzewiem wewnętrznych konfliktów, który determinować będzie funkcjonowanie państw i społeczeństw zachodniobałkańskich. W państwach zachodniobałkańskich zarówno opozycja, jak i ugrupowania rządzące wykorzystują kryzys migracyjny dla własnych celów politycznych nierzadko kosztem procedur demokratyzacyjnych, czego przykładem jest Macedonia (Szpala, 2016).

Implikacje kryzysu migracyjnego należy rozpatrywać nie tylko na poziomie poszczególnych państw, jak również w kontekście relacji dwustronnych. W tym miejscu przypomnieć należy, iż kwestia budowania relacji dwustronnych jest szczególnie istotna $\mathrm{w}$ kontekście bezpieczeństwa $\mathrm{w}$ regionie oraz europejskiej perspektywy państw zachodniobałkanskich. $\mathrm{Z}$ uwagi, iż region ten wciąż postrzegany jest jako wyzwanie z punktu widzenia bezpieczeństwa europejskiego współpraca sąsiedzka odgrywa istotne znaczenie $\mathrm{i}$ jest jednym $\mathrm{z}$ warunków integracji. W momencie eskalacji kryzysu migracyjnego masowy napływ migrantów na terytorium państw zachodniobałkańskich stał się jednym z czynników determinujących relacje dwustronne. Podkreślić należy, iż do czasu wypracowania wspólnych rozwiązań w regionie - co istotne przy udziale i wsparciu instytucji unijnych - państwa bałkańskie nawzajem obarczały się odpowiedzialnością za eskalację kryzysu, zwracając uwagę na partykularyzm działań i przerzucanie odpowiedzialności na sąsiadów. Podejmowane jednostronnie decyzje wywoływały efekt domina w kolejnych państwach, przez które przebiegał szlak migracyjny (Europejski, 2015). Co istotne, taki stan rzeczy wynikał z nieprzygotowania struktur administracyjnych państw zachodniobałkańskich do radzenia sobie z sytuacją, jaką wywołał napływ ludności, brakiem ich zdolności organizacyjnych i finansowych, po części także zlekceważeniem problemu w początkowej fazie.

W tym miejscu należy przypomnieć, iż przez państwa Bałkanów Zachodnich przebiega jeden z zasadniczych szlaków tranzytowych migrantów z Bliskiego Wschodu i Afryki będący przedłużeniem wschodniośródziemnomorskiego szlaku tzw. szlak zachodniobałkański biegnący z Turcji przez Grecję, Macedonię, Serbię do Węgier, i dalej do Austrii, Niemiec i Szwecji. Nadmienić warto również, iż część migrantów z Bliskiego Wschodu wybierała trasę do Serbii przez Bułgarię, ale była to - co ważne - rzadziej wybierana trasa (The Balkan Route, 2015). Warto zauważyć, iż trasy przerzutu migrantów zmieniały się wraz z modyfikacją polityki państw zachodniobałkańskich ulokowanych na szlaku migracyjnym. Niewywiązywanie się z prawnych zobowiązań zarówno przez państwa unijne (np. Grecji dotyczące rejestracji uchodźców), jak i niezdolność struktur administracyjnych państw nieunijnych do reagowania 
w sytuacji napływu migrantów determinowało pozostałe państwa do podejmowania jednostronnych decyzji. Podejmowane działania nie rozwiązywały problemu napływu uchodźców i imigrantów ekonomicznych, a jedynie wpływały na sytuację w innym państwie, przenosząc na nie ciężar odpowiedzialności, i co ważne, konfliktując je wzajemnie. Przykładem jest chociażby decyzja Węgier o budowie ogrodzenia na granicy z Serbią i zaostrzenie ich polityki migracyjnej. Konsekwencją powyższych działań było otwarcie nowej trasy tranzytowej, tym razem przez Chorwację. Jak zauważa Tomasz Żornaczuk, decyzja Węgier spowodowała przerzucenie ciężaru odpowiedzialności na Chorwację, która finalnie nie poradziła sobie z rejestracją migrantów i w efekcie umożliwiała dotarcie im do granicy z Węgrami. Jednocześnie Chorwacja, poszukując sposobów na zahamowanie i kontrolę napływu imigrantów, zaostrzyła strategię wobec sąsiadującej z nią Serbii. Zamknięcie przez Chorwację siedmiu z ośmiu przejść granicznych z Serbią negatywnie wpłynęło na chorwacko-serbskie relacje. Równocześnie zdecydowano o przekierowaniu części migrantów w stronę Słowenii. W konsekwencji pojawiły się problemy w stosunkach chorwacko-słoweńskich (Żornaczuk, 2015).

Reasumując należy wyraźnie zaznaczyć, iż polityka państw regionu wobec kryzysu migracyjnego determinowana była przez szereg czynników. Po pierwsze, polityka państw regionu w dużym stopniu zdeterminowana została przez Węgry, które konsekwentnie utrzymując sztywne reguły i de facto prowadząc antyimigranckie działania modelowały zachowania pozostałych państw regionu. Po drugie, wzajemne obarczanie się odpowiedzialnością, i co najważniejsze, przenoszenie ciężaru odpowiedzialności na państwa sąsiednie nie rozwiązywało problemu, a jedynie pogarszało wzajemne relacje. W przypadku państw zachodniobałkańskich obciążonych trudną przeszłością każda kolejna kontrowersja negatywnie warunkowała mozolnie wypracowany stan stabilności w stosunkach dwustronnych. Dodatkowo należy nadmienić, iż fiasko działań niektórych państw w zakresie kontroli napływu imigrantów wynikało z postawy sąsiadów i prób wykorzystywania kryzysu migracyjnego w celu rozwiązania problemów sąsiedzkich. Wystarczy wskazać przykład Macedonii. Jednym z kluczowych powodów, dla których państwo to nie było w stanie poradzić sobie z problemem imigrantów, był brak dostatecznej współpracy z Grecją (Biernat, 2015). Problemy Macedonii w początkowej fazie kryzysu (lato 2015) spowodowane były nie tylko niezdolnością struktur państwa do kontroli granic i ograniczenia przepływu osób, ale również polityką Grecji, która przestała kontrolować przepływ migrantów, a nawet ułatwiała im szybkie opuszczenie państwa, co zwiększało presję na granicy macedońsko-greckiej (Szpala, Jaroszewicz, 2015). Po trzecie, poszczególne państwa zachodniobałkańskie w różnym stopniu obciążone były napływem migrantów. Nie wszystkie państwa wybierane były przez migrantów jako państwa tranzytowe. Niezależnie od ich gotowości do przyjęcia i udzielenia wsparcia migrantom z uwagi na stopień trudności jaki towarzyszył podróży przez ich terytoria nie były one rozważane jako potencjalne państwa tranzytowe. $\mathrm{W}$ tym przypadku mowa o BiH. Ewentualne przejście przez ten kraj należy uznać za drogę niezwykle długą i niebezpieczną z uwagi na fakt, iż na terytorium Bośni znajdują się pola minowe, z których część nie jest nawet oznaczona na mapie (Biernat, 2015). Po czwarte, mając na uwadze rolę, jaką państwa Bałkanów Zachodnich odgrywają w kontekście kryzysu migracyjnego w UE (regionu tranzytowego) i posiadane zasoby, kluczowe znaczenie odgrywa polityka UE i jej strategia działania na rzecz kontroli napływu imigrantów. Co ważne, 
to UE koordynując działania na rzecz uchodźców i migrantów ekonomicznych, a także przejmując inicjatywę w tym zakresie pełni, zarazem rolę stabilizatora w regionie. Inercja jaka towarzyszyła UE w pierwszej fazie kryzysu migracyjnego spowodowała, iż państwa zachodniobałkańskie, nie będąc zdolnymi do współpracy, w zakresie kontroli napływu, podejmowały samodzielne decyzje nierzadko sprzeczne $\mathrm{z}$ interesem pozostałych państw. Abstrahując od głębszej analizy powodów tego stanu rzeczy podkreślić należy rolę UE jako gwaranta i stabilizatora $\mathrm{w}$ regionie. Również to od UE zależało przyjęcie wspólnego i skoordynowanego podejścia przez państwa Bałkanów Zachodnich w kontekście kryzysu migracyjnego.

Nadmienić należy, iż szlak zachodniobałkański do momentu jego zamknięcia w marcu 2016 roku pozostawał najpopularniejszym sposobem dotarcia na terytorium UE. Jego zamknięcie (7 marca 2016 r.) oraz zawarcie porozumienia pomiędzy UE a Turcją (20 marca 2016 r.), które skutkować miało wzmocnieniem przez Turcję kontroli granic morskich i walką z przemytnikami ludzi oraz przyjmowaniem z powrotem wszystkich migrantów, którzy nielegalnie przedostali się z tureckiego terytorium do Grecji, w przyszłości nie rozwiązały ostatecznie problemu z nielegalną migracją na terytorium Unii. Pomimo działań ze strony państw Bałkanów Zachodnich, a przede wszystkim UE wraz z zamykaniem i uszczelnianiem jednych tras tranzytowych pojawiały się kolejne trasy przerzutu, chociażby wiodąca z Grecji przez Albanię, Czarnogórę, Chorwację, Słowenię, a nawet kilka kilometrów przez Bośnię (Nemanja, Jarecka, 2016). Pomimo zdecydowanego ograniczenia napływu migrantów w przyszłości wykorzystywano szlak zachodniobałkański do ich przerzutu o czym informowały władze Austrii (Austria, 2017). Zjawisko to potwierdza raport przygotowany przez Instytut Friedrich Ebert Stiftung. W raporcie zwraca się uwagę, iż podjęte działania zdecydowanie ograniczyły napływ imigrantów jednakże nie wyeliminowały procederu przerzutu ludzi, a jedynie trasa przepływu imigrantów zmieniła kierunek i prowadzi z greckich wysp przez granicę lądową Bułgarii z Turcją. Poprzednio imigranci przybywali do Serbii, natomiast obecnie imigranci pozostają w Bułgarii (Weber, 2017). Co ważne, dla imigrantów, którzy znaleźli się w Bułgarii oraz Macedonii i Serbii w rzeczywistości są to jedynie państwa tranzytowe, a nie docelowe. W raporcie zwraca się uwagę na znaczenie umowy pomiędzy UE a Turcją dla utrzymania sytuacji w zakresie przepływu osób. Zarazem jednak wyrażane są wątpliwości co do trwałości obecnych procedur i struktur na Bałkanach, w sytuacji gdyby doszło do masowego napływu uchodźców (Weber, 2017).

Szczególnie istotny jest jednak fakt wpływu kryzysu migracyjnego zarówno na relacje dwustronne państw bałkańskich jak również na współpracę regionalną. Z uwagi na nieodległą przeszłość, kiedy to na obszarze b. Jugosławii toczył się krwawy konflikt, w który zaangażowane były dziś już niepodległe państwa Bałkanów Zachodnich, to poprawne relacje pomiędzy niedawanymi stronami konfliktu są szczególnie ważne z punktu widzenia stabilizacji regionu. Kryzys migracyjny, antagonizując państwa w regionie, które samodzielnie zgodnie ze swoim rozumieniem interesu narodowego podejmują środki zaradcze, może negatywnie warunkować proces umacniania bezpieczeństwa i stabilności regionu Bałkan Zachodnich. Opinie o implikacjach kryzysu migracyjnego z perspektywy bezpieczeństwa i stabilności na obszarze Bałkanów Zachodnich nie są odosobnione. Wyraził je m.in. szef MSZ Niemiec Frank-Walter Steinmeier, ostrzegając przed ożywieniem konfliktów między krajami byłej Jugosławii z powodu sporów 
o rozwiązanie kryzysu imigracyjnego (Uchodźcy, 2015). Na możliwe konsekwencje dla bezpieczeństwa w regionie wskazywał również premier Słowenii Miro Cerar (Premier, 2016). Wprawdzie pogląd o możliwym konflikcie czy wojnie na Bałkanach jako konsekwencjach kryzysu migracyjnego nie są powszechnie podzielane, jednakże zwraca się uwagę na fakt, iż kryzys migracyjny uzewnętrznił trudności w relacjach dwustronnych (Wojna, 2015). Ponadto dyskusja o kryzysie i jego możliwych konsekwencjach przebiega w ożywionej atmosferze, w której formułowane są niezwykle wyraziste opinie. Dodatkowo retoryka i argumentacja, jaka towarzyszy kryzysowi migracyjnemu, jest podyktowana partykularnymi celami poszczególnych państw. Inaczej kwestię kryzysu migracyjnego postrzegają państwa członkowskie UE, zwłaszcza te, które są celem wędrówek migrantów, a inaczej widzą to państwa nieunijne aspirujące do członkostwa.

Kryzys migracyjny obok wielu negatywnych następstw, jakie implikuje, zobligował państwa bałkańskie do poszukiwania mechanizmów współpracy i koordynacji działań. Indywidualna praktyka reagowania na kryzys migracyjny nacechowana indywidualizmem i brakiem solidarności, okazując się nieskuteczną w sytuacji niekontrolowanego napływu imigrantów, zobligowała państwa w regionie do współdziałania. Zarządzanie przepływami migracyjnymi przerosło bowiem zdolności i możliwości pojedynczych państw i jedynie wspólne działania przy wsparciu instytucji europejskich mogły przynieść pożądany efekt. Warto nadmienić, iż pierwsze porozumienie dotyczące kontroli przepływu migrantów pomiędzy państwami zlokalizowanymi na szlaku zachodniobałkańskim zarówno między członkami UE, jak i państwami nieunijnymi (Macedonia, Serbia, Słowenia, Chorwacja, Austrii) zawarto już jesienią 2015 roku. Niezależnie od fiaska, zarówno tych działań (spowodowanych m.in. liczbą uchodźców, brakiem przygotowania administracji, wewnętrznymi uwarunkowaniami np. wybory parlamentarne w Chorwacji), jak również unijnych inicjatyw (m.in. plan przyjęty na szczycie UE-Bałkany w październiku 2015 r.) w przyszłości poszukiwano skuteczniejszych mechanizmów współpracy. Ograniczanie przypływu migrantów (poprzez uszczelnienie granicy grecko-macedońskiej) stało się celem wszystkich państw ulokowanych na trasie zachodniobałkańskiej i niezależnie od krytyki, z jaką spotykały się ich działania ze strony części państw członkowskich UE (np. Grecja, Niemcy) konsekwentnie forsowano rozwiązania, które miały ów cel zrealizować (Szpala, Frymark, 2016).

Wzrost liczby imigrantów napływających do Europy i przekraczających granice UE stanowi dziś jeden z czynników determinujących współpracę w regionie. Co ważne, reakcja państw bałkańskich na kryzys migracyjny jest odmienna i determinowana szeregiem czynników. Zależy ona od presji migracyjnej, jaką doświadczają poszczególne państwa i konsekwencji, jakie są związane z napływem imigrantów na ich terytoria. Przede wszystkim należy mieć na uwadze fakt, iż państwa Bałkanów Zachodnich są przede wszystkim państwami tranzytowymi dla imigrantów, a nie docelowymi.

\section{Rozszerzenie UE o Bałkany Zachodnie a kryzys migracyjny}

Napływ imigrantów na terytorium UE stanowi dziś jeden z czynników, który z jednej strony, implikuje politykę państw Bałkanów Zachodnich wobec Unii Europejskiej, z drugiej zaś, determinuje jej politykę wobec regionu i wpływa na proces rozszerzenia. 
Rozważając reperkusje kryzysu migracyjnego dla procesu akcesji do UE kolejnych państw aspirujących do członkostwa zauważyć należy, iż kryzys migracyjny nie jest jedynym czynnikiem, który warunkuje tempo rozszerzenia. Współcześnie, z uwagi na skalę i dynamikę zjawiska migracji do UE jest to istotny czynnik determinujący rozszerzenie, aczkolwiek co należy uwypuklić, nie jedyny. Mając na uwadze złożoną naturę czynników warunkujących rozszerzenie zarówno wewnątrzunijnych (politycznych, prawnych, instytucjonalnych, finansowych), jak i wynikających z uwarunkowań zewnętrznych kryzys migracyjny może odgrywać istotną rolę zarówno czynnika wzmacniającego tempo rozszerzenia, jak też hamującego. Podkreślić należy, iż o dynamice i charakterze procesu rozszerzenia decydują złożone i wzajemnie warunkujące się procesy i zjawiska ulokowane na wielu poziomach, a mianowicie na poziomie państw kandydujących, na poziomie państw członkowskich oraz na poziomie UE (instytucje, polityka rozszerzenia i jej realizacja) (Szymański, 2009, s. 309). W pierwszym przypadku istotną rolę odgrywa determinacja państw kandydujących zdolnych i gotowych do inkorporacji zasad, wartości i norm prawnych, którym hołduje UE - jest to warunek podstawowy dla państw kandydujących. Drugi zespół czynników, który należy wyeksponować, a który determinuje proces rozszerzenia UE tkwi w zdolności UE do inkorporacji kolejnych państw, a nadto w polityce i postawach poszczególnych państw członkowskich, które w odniesieniu do państw Bałkanów Zachodnich przypominają o potrzebie spełnienia rygorystycznych kryteriów (Podgórzańska, 2016, s. 58-62). Pomimo rzeczywistych postępów części państw regionu w wypełnianiu warunków członkostwa - co znajduje odzwierciedlenie w kolejnych fazach zbliżania ze strukturami unijnej współpracy - istnieje szereg obszarów, w których Unia od lat odnotowuje uchybienia. Każde z państw Bałkanów Zachodnich znajduje się na innym etapie integracji i każde zmaga się z innymi problemami politycznymi, społecznymi, gospodarczymi, narodowościowymi. Stanowią one impuls do formułowania krytycznych uwag na temat możliwości akcesyjnych i zdolności regionu do inkorporowania unijnych reguł. Rygorystyczne egzekwowanie wymogów formalnych z założenia ma doprowadzić do sytuacji, w której nowoprzyjęte państwa członkowskie będą zdolne do funkcjonowania w ,europejskiej rodzinie” i cechować się będą tożsamymi dla wszystkich państw członkowskich normami i zasadami (Podgórzańska, 2016, s. 62-66). Trzeci zespół czynników ma związek z rozwojem sytuacji w otoczeniu UE, charakterem zagrożeń, które mogą mieć niekorzystny wpływ na funkcjonowanie UE. Czwarty zespół czynników tworzą wewnątrzunijne polityczne, gospodarcze, społeczne uwarunkowania, które mogą decydować o tempie rozszerzenia UE, zarówno o państwa z obszaru Bałkan Zachodnich, jak również i pozostałe państwa aspirujące.

Przyjmuje się, iż kryzys migracyjny nie musi oznaczać rezygnacji UE z realizowania strategii rozszerzeniowej, wręcz przeciwnie, może okazać się czynnikiem wzmacniającym aktywność Unii i zachęcającym instytucje unijne do wykazania zdolności absorpcyjnych tej organizacji. Inaczej niż kryzys finansowy i gospodarczy, z którymi kilka lat temu zmagała się UE kryzys migracyjny nakładając się na inne jakże istotne w skutkach wydarzenie związane z brytyjskim referendum z 23 czerwca 2016 roku i decyzją o opuszczeniu przez Zjednoczone Królestwo UE stanowić może impuls do przewartościowania i przemodelowania dotychczasowej aktywności rozszerzeniowej UE. Co ciekawe bowiem formułowany jest pogląd, iż paradoksalnie Brexit może 
korzystnie wpłynąć na tempo akcji (UE straci, 2016). Czynnikiem działającym na korzyść państw bałkańskich jest potrzeba udowodnienia przez UE posiadanych zdolności i siły przyciągania nowych członków. Równocześnie zauważa się, iż sytuacja, w której znalazła się UE nie oznacza rezygnacji z dotychczasowych wymogów formalno-prawnych stawianych potencjalnym członkom. Wręcz przeciwnie konsekwentnie powtarzana jest teza o konieczności sprostania rygorystycznym wymaganiom, przywiązania do wartości utożsamianych przez UE i wkomponowania się w założenia unijnej polityki.

Rozważając implikacje kryzysu migracyjnego z perspektywy rozszerzenia UE, należy mieć na uwadze kontekst wydarzeń związanych z niekontrolowanym napływem imigrantów i rolę, jaką odgrywa region. Popularność szlaku zachodniobałkanskiego wśród migrantów spowodowała, iż państwa zlokalizowane na trasie ich wędrówek stały się kluczowe z punktu widzenia kontroli granic i ograniczenia napływu migrantów. Ścisła współpraca UE zarówno z Turcją, jak i państwami zachodniobałkańskimi aspirującymi do członkostwa w UE, w sytuacji narastającego kryzysu uchodźczego, stała się kluczowa. Z uwagi na rolę jaką odgrywają w kryzysie migracyjnym pojawiała się możliwość zdynamizowania procesu akcesji. W opinii Adama Szymańskiego niezależnie od niekorzystnego wpływu kryzysu migracyjnego na proces akcesji państw Bałkanów Zachodnich wyróżnić można kilka kwestii świadczących o tym, że kryzys migracyjny nie szkodzi procesowi przedakcesyjnemu obecnych kandydatów, a wręcz jest czynnikiem wpływającym korzystnie na relacje z Unią Europejską. W jego ocenie przede wszystkim nie widać wyraźnego spowolnienia procesu przedakcesyjnego. Ponadto kryzys migracyjny przyczynia się do zwiększenia różnego rodzaju pomocy ze strony UE dla państw kandydujących w dziedzinach mieszczących się przede wszystkim w obszarze wolności, bezpieczeństwa i sprawiedliwości, związanych z kontrolą i zarządzaniem legalną oraz nielegalną migracją, polityką azylową i wizową. Z punktu widzenia perspektyw polityki rozszerzenia UE istotne jest również to, że kryzys uchodźczy przyczynia się do ogólnego ożywienia procesu przedakcesyjnego, przynajmniej części kandydatów (poza obszarem wolności, bezpieczeństwa i sprawiedliwości) (Szymański, 2016, s. 249-254). Co ważne w opinii przywołanego autora w dłuższej perspektywie instytucje unijne będą zwracać baczną uwagę na problemy kandydatów w spełnianiu kryteriów członkostwa. Dlatego też korzystny wpływ kryzysu uchodźczego na politykę rozszerzania UE będzie jednak umiarkowany. Przede wszystkim perspektywa akcesji zależeć będzie od postępów w radzeniu sobie z tym kryzysem, skali problemów, które mogą się pojawić wraz z implementacją przyjętych rozwiązań i efektywności współpracy instytucji unijnych, państw członkowskich i krajów kandydujących do członkostwa (Szymański, 2016, s. 254).

Zauważyć jednak należy, iż o ile kryzys migracyjny nie musi w sposób znaczący wpłynać na tempo akcesji państw zachodniobałkańskich to zarazem perspektywa akcesji musi wciąż zajmować kluczowe miejsce w relacjach UE-Bałkany Zachodnie. Przemawia za tym szereg przesłanek, chociażby taka, iż proces rozszerzenia jest efektywnym mechanizmem wzmacniającym procesy transformacyjne i modernizacyjne w regionie, wzmacnia system rządów prawa i praw człowieka w tych państwach, pobudza rozwój gospodarczy i sprzyja współpracy regionalnej, wzmacnia stabilność i służy bezpieczeństwu europejskiemu. Równie istotne znaczenie może odgrywać rola 
Rosji, która systematycznie podejmuje działania na rzecz zwiększenia swej aktywności. Tradycyjnie obecna $w$ tym regionie pomimo, iż jej strategiczne interesy nie są ściśle z nim związane, dążyć może do zaznaczenia swej obecności oraz zaangażowania, i co ważne, wpływania na procesy polityczne i gospodarcze tam zachodzące (Stępniewski, 2015, s. 53-54; Hoxha, Ahmeti, Musliu, 2015, s. 71-78). Jak zauważa Marta Szpala, kontynuowanie polityki désintéressement przez UE, biorąc pod uwagę działania Rosji, może zaowocować destabilizacją regionu, którego znaczenie dla bezpieczeństwa UE pokazał choćby kryzys migracyjny z 2015 roku. W jej ocenie tylko zintegrowane z Unią Bałkany Zachodnie mogą skutecznie blokować napływ nielegalnej imigracji czy przeciwdziałać transgranicznej przestępczości zorganizowanej i zwalczać grupy terrorystyczne (Szpala, 2017, s. 4). Tradycyjne wpływy Rosji w tym regionie i stosowane przez nią instrumenty oddziaływania na państwa bałkańskie mogą osłabić dążenia państw regionu do akcesji w struktury UE. W opinii Marko Babicia, dopóki istnieją perspektywy integracji z UE, atrakcyjność Rosji jako swoistego kontrmodelu politycznego i ideologicznego pozostaje raczej ograniczona. Zarazem zauważa, iż gdyby siła przyciaggania UE w regionie osłabła, wpływy Rosji mogłyby się wzmocnić (Babić, 2014, s. 69).

Reasumując, brak perspektywy akcesji państw Bałkanów Zachodnich do UE może osłabić procesy transformacji i modernizacji regionu. Niezależnie od obecnej sytuacji związanej z kryzysem migracyjnym niepokoją praktyki stosowane przez tamtejsze władze, które w efekcie skutkują osłabieniem proeuropejskich dążeń. Abstrahując od głębszej analizy powodów takiego stanu rzeczy należy podkreślić, iż jedynie jasno zakreślone warunki akcesji stanowią gwarancję utrzymania proeuropejskiego „klimatu” w regionie.

\section{Zakończenie}

Kryzys migracyjny z perspektywy państw Bałkanów Zachodnich skłania do sformułowania kilku wniosków. Po pierwsze, z uwagi na status państwa tranzytowego w mniejszym stopniu ponoszą konsekwencje kryzysu migracyjnego, niż Grecja, czy Włochy, do których w pierwszej kolejności trafiają imigranci czy też państwa docelowe jak chociażby Niemcy. Przy czym nie oznacza to braku reperkusji napływu imigrantów na ich terytorium chociażby w kontekście wspomnianego bezpieczeństwa wewnętrznego. Mając na uwadze powyższe konsekwencje należy zwrócić uwagę na zdolności państw Bałkanów Zachodnich do reagowania w sytuacji napływu imigrantów. Potencjał każdego z nich jest ograniczony i każde z osobna nie jest $\mathrm{w}$ stanie przeciwdziałać potencjalnym zagrożeniom i, co najważniejsze, udzielić wsparcia imigrantom. Dodatkowo Serbia, Bośnia i Hercegowina czy Kosowo to państwa, które same muszą radzić sobie wciąż z problemem migracji osób wewnętrznie przesiedlonych po konfliktach, jakie toczyły się na obszarze b. Jugosławii. Po drugie, oddziaływanie kryzysu migracyjnego na poszczególne państwa w regionie jest zróżnicowany. Szczególne obowiązki ciążą na tych, które zlokalizowane są bezpośrednio na szlaku tranzytu migrantów. Po trzecie, kryzys migracyjny uwypuklił mankamenty dotychczasowej współpracy państw regionu, akcentując różnice stanowisk i postaw w kontekście sposobów radzenia sobie z następstwami kryzysu. Równocześnie to kryzys migracyjny 
wykazując słabości samodzielnych prób jego rozwiązania zmotywował państwa regionu do poszukiwania różnorodnych formuł współpracy. I co istotne, w kontekście europejskich aspiracji regionu, paradoksalnie wzmacniając powiązania pomiędzy państwami bałkańskimi przyspiesza realizację wytycznych polityki rozszerzenia UE. Po czwarte, żadne z państw regionu nie stanowi punktu docelowego dla imigrantów, a jednie państwo tranzytowe w ich drodze do zasobniejszych państw zachodnich. Po piąte, kryzys migracyjny może mieć dynamizujący wpływ na proces integracji państw zachodniobałkańskich z UE z zastrzeżeniem wypełniania przez nie wymogów formalnych. Kryzys migracyjny spowodował ponowne zainteresowanie UE regionem Bałkan Zachodnich, który stał się kluczowy z perspektywy zarządzania migracjami. Rola, jaką odrywa region w zakresie kontroli i regulowania procesem przepływu migrantów, może stanowić czynnik wspomagający proces akcesji.

Unia Europejska w znacznym stopniu przyczyniała się do złagodzenia napływu migrantów na terytorium Bałkan Zachodnich poprzez pomoc materialną i w konsekwencji wiedzę fachową. Nie rozwiązuje to jednak ich trudnej sytuacji (np. Serbii czy Macedonii), która po zamknięciu szlaku bałkańskiego stała się jeszcze bardziej skomplikowana z uwagi zarówno na konieczność udzielenia wsparcia tym, którzy znaleźli się na ich terytorium, jak i na problem kontroli granic i ochrony przed nielegalnym ich przekraczaniem.

\section{Bibliografia}

Asylum decisions in the EU (2017), EU Member States granted protection to more than 700000 asylum seekers in 2016, http://ec.europa.eu/eurostat/documents/2995521/8001715/3-26042017AP-EN.pdf/05e315db-1fe3-49d1-94ff-06f7e995580e, 12.07.2017.

Asylum quarterly report (2017), http://ec.europa.eu/eurostat/documents/6049358/7005580/Asylum+Quarterly+Report+-+Q3+2016.pdf/2ad7a4f9-495f-4480-9ed9-1d08a54b4611, 12.07.2017.

Austria ostrzega: Szlakbałkański wcaleniejest zamknięty, 11.03.2017, http://fakty.interia.pl/deutschewelle/news-austria-ostrzega-szlak-balkanski-wcale-nie-jest-zamkniety,nId,2367343\#utm_ source=paste\&utm_medium=paste\&utm_campaign=chrome, 12.07.2017.

Babić M. (2014), Rosja na Batkanach Zachodnich. Interesy narodowe i wplywy polityczne, w: Batkany w XXI wieku Problemy konsolidacji i integracji, red. M. Babić, I. Jakimowicz-Ostrowska, Wydział Dziennikarstwa i Nauk Politycznych Uniwersytet Warszawski, Warszawa.

Biernat A., Bałkany wobec kryzysu migracyjnego, https://pulaski.pl/analiza-balkany-wobec-kryzysumigracyjnego/, 11.07.2017.

Bokajło J. (2008), Regionalizacja i europeizacja Bałkanów Zachodnich, w: Regionalizacja w stosunkach międzynarodowych. Aspekty polityczno-gospodarcze, red. K. Jędrzejczyk-Kulniak, L. Kwieciński, B. Michalski, E. Stadmüller, Wydawnictwo Adam Marszałek, Toruń.

Bonikowska M., Szczygielski M., Zabielski S. (2016), Unia Europejska na scenie globalnej: zjednoczeni czy nieistotni?, CSM, $\mathrm{nr} 4$.

Borkowski P. (2016), Wymiar polityczny uchodźstwa - wybrane problemy w kontekście europejskiego kryzysu migracyjnego, w: Uchodźcy w Europie. Uwarunkowania, istota, nastęstwa, red. K. A. Wojtaszczyk, J. Szymańska, Oficyna Wydawnicza ASPRA-JR, Warszawa.

Cesarz M. (2016), Kryzys uchodźczy w Europie - zarys problemu, w: Uchodźcy w Europie. Uwarunkowania, istota, nastęstwa, red. K. A. Wojtaszczyk, J. Szymańska, Oficyna Wydawnicza ASPRA-JR, Warszawa. 
Czachór Z., Jaskólski A. (2015), Polska wobec kryzysu migracyjnego w Europie, Instytut Obywatelski, http://www.instytutobywatelski.pl/wp-content/uploads/2016/06/Analiza_Polska-wobeckryzysu.pdf, 10.07.2017.

Duszczyk M. (2015), Kryzys migracyjny czy kryzys Unii Europejskiej?, http://www.iz.poznan. pl/plik,pobierz,91,c1d90926dcef3f4fd9bc492b52bd8268/1291-Problem-uchodzczy.pdf, 10.07.2017.

El Ghamari M. (2016), Ekspansja Daesh na Bałkanach. Albania, Kosowo i Bośnia zagrożone, http://www.defence24.pl/290363, ekspansja-daesh-na-balkanach-albania-kosowo-i-bosniazagrozone, 11.07.2017.

European Union terrorism situation and Trend Report 2017 (2017), https://www.europol.europa. eu/activities-services/main-reports/eu-terrorism-situation-and-trend-report-te-sat-2017, 11.07.2017.

Europejski program w zakresie migracji: Grecja, Włochy, Bałkany Zachodnie (2015), https://www.euractiv.pl/section/polityka-wewnetrzna/press_release/realizacja-europejskiego-programu-w-zakresie-migracji-sprawozdania-z-postepow-grecja-wlochy-i-balkany-zachodnie/, 12.07.2017.

Fiszer J. M. (2015), Kryzys integracji europejskiej czy kryzys Unii Europejskiej? Przesłanki i skutki, „Przegląd Europejski”, nr 3.

Greenhill K. (2016), Open Arms Behind Barred Doors: Fear, Hypocrisy and Policy Schizophrenia in the European Migration Crisis, „European Law Journal”, vol. 22, nr 3.

Hoxha A., Ahmeti A., Musliu A. (2015), Russian Influence in the Western Balkans. Carrot or Stick?, „Rocznik Instytutu Europy Środkowo-Wschodniej”, r. 13, z. 5.

Izak K. (2013), Radykalny islam na Bałkanach źródtem konfliktów społecznych i terrorystycznego zagrożenia dla Europy, „Rocznik Bezpieczeństwa Wewnętrznego”, nr 9.

Kosowski exodus (2015), „Biuletyn Migracyjny, nr 51, http://biuletynmigracyjny.uw.edu.pl/51czerwiec-2015/kosowski-exodus, 14.07.2017.

Kotowska M., Pływaczewski W. (2015), Przemyt imigrantów jako obszar zainteresowania członków zorganizowanych grup przestępczych. Studium przypadku, w: Uchodźcy - nowe wyzwania dla bezpieczeństwa europejskiego na tle standardów praw człowieka, red. W. Pływaczewski, M. Ilnicki, Katedra Kryminologii i Polityki Kryminalnej Wydział Prawa i Administracji Uniwersytet Warmińsko-Mazurski w Olsztynie, Olsztyn.

Kryzys imigracyjny - eldorado dla kryminalistów. Prostytucja, handel narkotykami, kontrola ośrodków dla uchodźców - tak organizacje przestępcze zarabiaja na chaosie w Europie (2016), 26.02.2016, https://wiadomosci.wp.pl/kryzys-imigracyjny-eldorado-dla-kryminalistow-prostytucja-handel-narkotykami-kontrola-osrodkow-dla-uchodzcow-tak-organizacje-przestepcze-zarabiaja-na-chaosie-w-europie-6027654785180289a, 12.07.2017.

Kryzys migracyjny. Rosna obawy państw bałkańskich (2016), 25.01.2016, http://www.dw.com/ $\mathrm{pl} /$ kryzys-migracyjny-rosn $\% \mathrm{C} 4 \% 85$-obawy-pa\%C5\%84stw-ba\%C5\%82ka\%C5\%84skich/ a-19001646, 14.07.2017.

Lindley A. (2014), Exploring crisis and migration: concepts and issues, w: Crisis and Migration. Critical perspectives, red. A. Lindley, Routledge Taylor and Francis Group, Londyn-Nowy York.

Managing the EU migration crisis From panic to planning (2016), http://www.ey.com/Publication/ vwLUAssets/ey-managing-the-eu-migration-crisis/\%24FILE/ey-managing-the-eu-migration-crisis.pdf, 12.07.2017.

Metcalfe-Hough V. (2015), The migration crisis? Facts, challenges and possible solutions, 20.10.2015, https://www.odi.org/publications/9993-migration-crisis-facts-challenges-andpossible-solutions, 10.07.2017.

Nemanja R., Jarecka A., Szlak bałkański i nowe trasy uchodźców do UE, 18.02.2016, http://www. dw.com/pl/szlak-ba\%C5\%82ka\%C5\%84ski-i-nowe-trasy-uchod\%C5\%BAc\%C3\%B3w-doue/a-19054894, 11.07.2017. 
Niekontrolowane migracje do Unii Europejskiej (2015), red. P. Sasnal, Warszawa, listopad 2015, https://www.pism.pl/files/?id_plik=20992. 14.07.2017.

Pachocka M. (2016), OECD wobec kryzysu migracyjnego i uchodźczego w Europie, „Komentarze", nr 20, Instytut Europy Środkowo-Wschodniej", https://depot.ceon.pl/bitstream/ handle/123456789/10264/OECD_wobec_kryzysu_migracyjnego_i_uchodz.pdf?sequence$=1 \&$ isAllowed $=\mathrm{y}$, 10.07.2017.

Podgórzańska R. (2014), Polityka zagraniczna Polski wobec państw obszaru pojugosłowiańskiego, Wydawnictwo Adam Marszałek, Torun.

Podgórzańska R. (2015), Problemy społeczne Bałkanów Zachodnich i ich implikacje dla procesu integracji europejskiej, w: Społeczne oblicza Europy XXI wieku, red. B. Koszel, D. Mierzejewski, Z. Popławski, Państwowa Wyższa Szkoła Zawodowa im. Stanisława Staszica w Pile, Piła.

Podgórzańska R. (2016), Implikacje kryzysu migracyjnego dla polityki rozszerzenia UE o Bałkany Zachodnie, w: Zagrożenia dla integracji europejskiej w XXI wieku, red. B. Koszel, D. Mierzejewski, Z. Popławski, Państwowa Wyższa Szkoła Zawodowa im. Stanisława Staszica w Pile, Piła.

Premier Stowenii ostrzega przed wojnq w Europie: ,, Gdyby szlak Bałkański został z powrotem otwarty, wybuchtby poważny konflikt w regionie" (2016), 7.09.2016, http://wpolityce.pl/swiat/ 307492-premier-slowenii-ostrzega-przed-wojna-w-europie-gdyby-szlak-balkanski-zostal-zpowrotem-otwarty-wybuchlby-powazny-konflikt-w-regionie, 12.07.2017.

Przestępczość zorganizowana na Bałkanach (2007), http://przestepczosczorganizowana.pl/index. php?go=45, 12.07.2017.

Raczyński R. (2015), Wpływ migracji międzynarodowych na bezpieczeństwo wewnętrzne państwa, „Bezpieczeństwo. Teoria i praktyka”, nr 2.

Saryusz-Wolski J. (2013), Unia Europejska wobec kryzysu, „Nowa Europa. Przegląd Natoliński”, nr 2.

Sprawozdanie ze spotkania międzyparlamentarnego na temat migracji przez Bałkany Zachodnie (2015), Sprawozdanie nr 10, Bruksela, 10 listopada br., Kancelaria Senatu, Przedstawiciel Kancelarii Senatu przy Unii Europejskiej, https://www.senat.gov.pl/senat-i-ue/sprawozdania-stalego-przedstawiciela-kancelarii-senatu-przy-ue/wspolne-spotkania-miedzyparlamentarne/, 12.07.2017.

Stępniewski T. (2015), Russia in Global Politics in the Context ofthe Western Balkans, „Rocznik Instytytu Europy Środkowo-Wschodniej”, r. 13, z. 5.

Szpala M. (2016), Macedonia: pozorna demokracja w cieniu kryzysów, https://www.osw.waw. pl/pl/publikacje/komentarze-osw/2016-04-01/macedonia-pozorna-demokracja-w-cieniukryzysow, 11.07.2017.

Szpala M. (2017), Bałkany Zachodnie coraz dalej od UE, http://orka.sejm.gov.pl/WydBAS.nsf/0/ E816F0D7A6E9A093C125812200434AD8/\$file/Infos_229.pdf, 12.07.2017.

Szpala M., Frymark K. (2017), Uszczelnianie zachodniobałkańskiego szlaku migracyjnego, 2.03.2016, https://www.osw.waw.pl/pl/publikacje/analizy/2016-03-02/uszczelnianie-zachodniobalkanskiego-szlaku-migracyjnego, 12.07.2017.

Szpala M., Jaroszewicz M., Macedonia a kryzys migracyjny, 26.08.2015, https://www.osw.waw.pl/ pl/publikacje/analizy/2015-08-26/macedonia-a-kryzys-migracyjny, 11.07.2017.

Szymański A. (2009), Teoretyczny i metodologiczny aspekt badań nad rozszerzeniem UE, w: Teoretyczne i metodologiczne wyzwania badań politologicznych w Polsce, red. A. Antoszewski, B. Krauz-Mozer, A. Dumała, Wydawnictwo UMCS, Lublin.

Szymański A. (2016), Kryzys uchodźczy a przyszłość unijnej polityki rozszerzenia, w: Uchodźcy w Europie. Uwarunkowania, istota, następstwa, red. K. A. Wojtaszczyk, J. Szymańska, Oficyna Wydawnicza ASPRA-JR, Warszawa. 
Szymczyński T. R. (2016), Brexit a wyzwania identyfikacyjne w odniesieniu do procesu integracji europejskiej z perspektywy hermeneutycznej, „Rocznik Integracji Europejskiej”, nr 10.

The Balkan Route: A Train passes through! (2015), 28.10.2015, http://www.dw.com/en/the-balkanroute-a-train-passes-through/a-18809756, 12.07.2017.

Uchodźcy? Nie mogq wzniecić konfliktów na Bałkanach (2015), 21.10.2015, http://www.rp.p1/ Uchodzcy/151029856-Uchodzcy-Nie-moga-wzniecic-konfliktow-na-Balkanach.html\#ap-1, 12.07.2017.

UE straci Wielkq Brytanię, ale zyska kraje bałkańskie? (2016), 5.07.2016, http://www.polskieradio.pl/7/1696/Artykul/1639830,UE-straci-Wielka-Brytanie-ale-zyska-kraje-balkanskie, 12.07.2017.

Weber B. (2017), The EU-Turkey Refugee Deal and the Not Quite Closed Balkan Route, http://library.fes.de/pdf-files/bueros/sarajevo/13436.pdf, 12.07.2017.

Western Balkans Quarterly Quarter 4, October-December 2016 (2017), http://frontex.europa.eu/ publications/, 14.07.2017.

Wojciechowski S. (2016), Uchodźcy a zagrożenie terrorystyczne na przykładzie Unii Europejskiej, w: Uchodźcy w Europie. Uwarunkowania, istota, nastepstwa, red. K. A. Wojtaszczyk, J. Szymańska, Oficyna Wydawnicza ASPRA-JR, Warszawa.

Wojna na Bałkanach? Kryzys migracyjny dzieli kraje byłej Jugosławii (2015), 27.10.2015, http:// www.polskieradio.pl/7/1696/Artykul/1537156, Wojna-na-Balkanach-Kryzys-migracyjnydzieli-kraje-bylej-Jugoslawii, 12.07.2017.

Wojtaszczyk K. A, Nadolska J., Czub J. F. (2014), Kryzysy w procesie integracji europejskiej i sposoby ich przezwyciężania - wprowadzenie do problematyki badań, „Przegląd Europejski”, nr 3 .

Wyzwania 2017. Imigracja i terroryzm (2016), http://ec.europa.eu/poland/news/161222_eurobarometer_pl, 12.07.2017.

Zięba R. (2016), Wspótczesne wyzwania i zagrożenia dla bezpieczeństwa międzynarodowego, „Stosunki Międzynarodowe - International Relations", t. 52, nr 3.

Żornaczuk T. (2015), Bałkańskie domino: niepewna przyszłość nowego szlaku migracyjnego przez Chorwację i Stowenię, „Biuletyn PISM”, nr 92, 22.10.2015.

Дачић: србија не може сама да реши проблем избеглииа (2015), 1.10.2015, http://mfa.gov.rs/sr/ index.php/pres-servis/vesti-od-znacaja?year=2015\&month=10\&day=01\&modid=77\&lang= cyr, 12.07.2017.

Мигрантска криза, као безбедносна претња републици србији (2017), 29.01.2017, http:// www.fsksrb.ru/fond-strateske-kulture/politika/migrantska-kriza-kao-bezbednosna-pretnjarepublici-srbiji/, 12.07.2017.

Пронаћи заједничко решеље за мигрантску кризу (2017), 19.05.2017, http://www.srbija.gov.rs/vesti/vest.php?pf=1\&id=293299\&url=\%2Fvesti\%2Fvest.php\%3Fpf\%3D1\%26id\%3D293299, 12.07.2017.

\section{Streszczenie}

Uwzględniając złożony charakter migracji, artykuł koncentruje się na problemie percepcji kryzysu z punktu widzenia Bałkanów Zachodnich, a przede wszystkim na wskazaniu implikacji kryzysu migracyjnego dla państw tego obszaru. Artykuł nie ma na celu całościowej analizy problemu migracji, koncentruje się jedynie na wybranych kwestiach postrzeganych jako istotne. Implikacje kryzysu migracyjnego dla państw zachodniobałkańskich należy rozpatrywać na kilku poziomach. Po pierwsze, należy mieć na uwadze konsekwencje, jakie wywołuje kryzys migracyjny na poziomie poszczególnych państw, chociażby w kontekście ich bezpieczeństwa. 
Drugi poziom analizy, to relacje dwustronne i implikacje kryzysu dla ich charakteru i dynamiki. Trzeci, to współpraca regionalna państw Bałkanów Zachodnich. Czwarty zaś, to relacje UE - państwa Bałkanów Zachodnich.

Kryzys migracyjny z perspektywy państw Bałkanów Zachodnich skłania do sformułowania kilku wniosków. Po pierwsze, oddziaływanie kryzysu migracyjnego na poszczególne państwa w regionie jest zróżnicowany. Po drugie, kryzys migracyjny uwypuklił mankamenty dotychczasowej współpracy państw regionu, akcentując różnice stanowisk i postaw w kontekście sposobów radzenia sobie z następstwami kryzysu. Po trzecie, żadne z państw regionu nie stanowi punktu docelowego dla imigrantów, a jedynie państwo tranzytowe w ich drodze do zasobniejszych państw zachodnich. Po czwarte, kryzys migracyjny może mieć dynamizujący wpływ na proces integracji z UE z zastrzeżeniem wypełniania przez państwa aspirujące wymogów formalnych.

Słowa kluczowe: kryzys migracyjny, Unia Europejska, Bałkany Zachodnie

\section{The migration crisis in the European Union from the Western Balkan perspective}

\section{Summary}

Considering the complex nature of the migration, the article focuses on the problem of perception of the crisis from the point of view of the Western Balkans, and above all on the implications of the migration crisis for the countries of the area. The article is not intended to be a holistic analysis of the migration issue. It concentrates only on selected aspects perceived as significant. The implications of the migration crisis for Western Balkan states should be considered at several levels. First of all, the implications of the migration crisis at the level of individual states should be taken into account, even in the context of their security. The second level of analysis is the bilateral relations of the countries of the Western Balkans and the implications of the crisis for their character and dynamics. The third is the regional cooperation of the countries of the Western Balkans. The fourth is the EU-Western Balkan relations.

The migration crisis from the perspective of Western Balkan states prompts a number of conclusions. First of all, the impact of the migration crisis on individual countries in the region is varied. Secondly, the migration crisis has highlighted the shortcomings of the region's cooperation, emphasizing differences in positions and attitudes in the context of coping with the aftermath of the crisis. Thirdly, none of the countries of the region is a destination for immigrants but a transit state on their way to more prosperous Western countries. Fourthly, the migration crisis can have a dynamic impact on the process of integration with the EU subject to the fulfillment of formal requirements by aspiring states.

Key words: migration crisis, European Union, Western Balkans 
